International Journal of English Literature and Social Sciences
Vol-6, Issue-2; Mar-Apr, 2021

\title{
Feminism Redefined: A Study of Atwood's Surfacing and Markandaya's Nectar in a Sieve
}

\author{
Dr. Anupriya Singh
}

Department of English, Swami Keshvanand Institute of Technology, Jaipur, India

E-mail: singhanupriyaa@yahoo.com

Received: 09 Jan 2021; Received in revised form: 11 Mar 2021; Accepted: 03 Apr 2021; Available online: 15 Apr 2021

(C)2021 The Author(s). Published by Infogain Publication. This is an open access article under the CC BY license

(https://creativecommons.org/licenses/by/4.0/).

\begin{abstract}
Feminism has become a very contentious issue now days. We have come across a number of definitions but none seems adequate enough to encompass all the situations which may or may not fall within the realm of feminism. In support of feminism, we have found people carrying out demonstrations, writing in the newspapers, giving speeches without attempting to know if the particular situation should be addressed under the banner of feminism. Recently, actor Swara Bhaskar in an open derisive letter to Sanjay Leela Bhansali accuses him of glorifying "Sati" and "Jauhar" in his film 'Padmaavat'. Even more ironical is the fact that people have formulated ethnically specific forms of feminism like Black feminism and Intersectional feminism, thus segregating the gender women according to race, class and religion.

This paper tries to explore two aspects related to feminism- First, should the definition of feminism be culture specific; Second, is it possible to have one universal definition which applies to all women on this earth. In order to address these issues, I have taken up the study of two novels in the light of the theory of Jean Paul Sartre who has often been accused of being hostile to women and an anti-feminist, thereby also proving that Sartre's concepts of "Bad faith", "Immanence" and "Freedom of Choice" are not abstract but universal.
\end{abstract}

Keywords-Bad faith, Being-for-itself Being-in-itself, Feminism, Freedom of choice.

\section{INTRODUCTION}

Feminism is, in fact, a very debatable and dubious issue. Before, I plunge myself into reviewing the concept of feminism, let us first have a look at the definition of feminism. Feminism includes a wide array of political movements, philosophies and social movements that share a common goal of establishing equality between both the sexes in all spheres of life. It also promotes for bodily autonomy and honor for women, and at the same time advocating protection of women and girls from rape, sexual harassment, and domestic violence. Changes in dress and acceptable physical activity have often been part of feminist movements. Some forms of feminism have often been criticized for taking into account only whites, middle class, and college educated perspectives which consequently led to the formulation of ethnically specific forms of feminism like Black feminism and Intersectional feminism.

Whatever little understanding and insight I have gained after reading feminist literature and being a part of an Indian society, I feel the need to redefine the concept of feminism. However, I am afraid that like Jean Paul Sartre, I would also be accused of being hostile to women and an anti-feminist. Sartre has often been alleged of never developing a truly feminist philosophy and was even blamed for talking disparagingly of women at certain places in his opus. After reading both the novels, I have concluded that women belonging to different cultures have their respective specific margins for "bodily autonomy" and the societies to which they belong also have their own specific threshold limits for "acceptable physical" activity. Sartre's concepts of Bad faith, Immanence, and Freedom of Choice are also not abstract as they have often been 
dubbed but they have a profound base and holds true in all times and situations, and therefore, Sartre's philosophy should be dubbed as universal feminist philosophy and not anti-feminist. I have applied the philosophy to both the novels and in its light attempted to redefine feminism.

\section{Application of Sartrean philosophy to Surfacing}

Surfacing is the novel written by Margaret Atwood. It is the story of an unnamed narrator, who returned to Quebec in search for her father. She was accompanied by her boyfriend Joe, and a married couple, Anna and David.The novel depicts comparison between the two female protagonists- the narrator and Anna.The narrator is shown as a strong woman capable of exercising her 'freedom of choice', while Anna is shown as a woman of weak will whose priority is to live up to the expectations of her husband, David, whom she has herself admitted to be a "womanizer".

There are several incidents in the novel which reinforce the purpose of this paper. Not invariably, but there are many instances when we get the impression that the female protagonists are being oppressed by males. On the secluded island, which was far away from the sophisticated life of the city, the narrator saw Anna doing make-up early in the morning. On being asked by the narrator, she says- "He doesn't like to see me without it" (Atwood, 2009, p.52). Thus, it is Anna who is responsible for reducing herself to an "object". Like David, Anna also considers husband- wife relationship as existing between two bodies, that is, material, physical. She warns her husband not to grow beard-"I don't like him kissing me when he has a beard, it reminds me of a cunt" (Atwood, 2009 , p.53). By this statement, one can very well conclude that Annais unaware of the ethereal nature of marital relationship. She believes in the physical and the material. The usage of word "cunt" is considered highly insulting and demeaning in a society. It is one of the most odious and powerful examples of verbal abuse in English language. Her enquiry from the narrator about her taking pills is another evidence which throws light on Anna's views regarding premarital and marital relationships. But the narrator's answer "not any more" is the antithesis of what Anna thinks. The narrator's answer clearly indicates that after she gets divorced, she doesn't require them anymore.

The narrator is shown as living with her boyfriend, Joe. Though like David, Joe is not shown as a person who treats woman as an object. He wants to marry Anna and does not have any intention to take undue advantage of her body, although, once he tried to enter into a premarital physical relationship with her, probably because of his intense love for her. However, the narrator strongly resisted any such advances made by Joe. The narrator considers marriage a very sacrosanct institution, where husband and wife should be loyal to each other. That is why her revelation about Anna and David's marriage as not a "good marriage" is quite shocking to her (Atwood, 2009, p.126). The narrator's experience with her exhusband made her reluctant to enter into a marital relationship with Joe. Her ex-husbandis shown as a person who considers woman as an object. As told by the narrator, that even at the time of delivery, he was not present with her. The narrator depicted the entire ordeal, she went through while delivering the baby. Her statement, "But he brought his car to collect me afterward, I didn't have to take a taxi" indicates the distressing state of her mind. Probably,this forced her to take the decision not to have another child and which probably compelled her to discourage any such advancements made by Joe.

The narrator's idea of motherhood is also very high. It is only later in the novel, we have come to know that, in fact, she had never given birth to a baby, but it was an abortion done deliberately by the consent of her husband. That is why, perhaps, she said, "He wasn't there with me, I couldn't remember why; he should have been, since it was his idea, his fault" (Atwood, 2009, p.101). This incident of abortion was reigning so high on her mind that when she jumped into the lake in order to find out the truth about certain paintings drawn by his father, she thought that the dead thing which she saw there might be the child which she didn't allow to come into the world-"whatever it is, part of myself or a separate creature, I killed it. It was a child but it could have been one, I didn't allow it" (Atwood, 2009, p.183).This reveals the guilt she has been suffering from on account of deliberate abortion of her child. But ultimately, it was her choice to act according to her husband's wish, and therefore solely responsible for her mental agony.

From the above discussion, it can be concluded that Surfacing cannot be dubbed as a feministic work. Both the female characters - Anna and the unnamed narrator are living their lives as per their choice. They themselves are responsible for their mental agony. Anna is still living with David because she loves him and cannot think of leaving him even after such an insulting incident when David went to the extent of stripping her in order to click her photos for his movie "Random Samples". At that time, she felt so humiliated that she jumped into the lake and remained in it for some time. But in spite of that, Anna continued to live with David because somewhere it is within the "acceptable" limits of Anna. Moreover, both believe in material and physical aspect of any relationship. Hence, it cannot be said that Anna is being harassed by David. On the other hand, the narrator is shown as a female of strong 
character. She thwarted several attempts made by David which were aimed at seducing her. Many a times, she discouraged Joe from establishing physical relationship with her, perhaps, not because of any moral obligation, but because of her bad experience from her previous marriage. But whatever is the reason, she is acting by her choice and not forced by anybody to act in a particular way.

I believe that the above discussion of the novel Surfacing provides a substantial evidence to prove that Sartre's existentialist notions of "freedom of choice" and "bad faith" are neither abstract nor anti-feminist. The contradiction between the two terms "bodily autonomy" and the "acceptable physical activity" has sufficiently supported it. The latter deters any person to exercise his/her freedom of choice. It stands in the way of "bodily autonomy", and thus the person is not true to oneself. On the other hand, if enough freedom is given to exercise one's choice then that person is solely responsible for the consequences. Freedom to make choice is associated with accountability and potential consequences which often put people into a quandary -to make a choice or not to make a choice and sometimes they fall into a pattern of blaming others and the world in order to escape from the responsibility of defining themselves. Because of all these fears and under pressure from social forces, people adopt ad-hoc values and beliefs and thus act inauthentically. This is called "Bad faith". It may be defined as the habit that people have of deceiving themselves (Burton, 2012; Flynn, 2004). They prefer to opt for the choice which is convenient for them and also acceptable to the society. In this process, they end up sacrificing their freedom to make choices for fear of impending repercussions. Thus, the person is more akin to an object than to a conscious human being, or, in Sartrean terminology, more akin to a "beingin-itself" than to a "being-for-itself"(Burton, 2012; Flynn, 2004).It can be said that Anna is more like "a being in itself", while the unknown narrator is "a being for itself".

Like females, males also have the right to think and act by their choice. To perceive females as objects is their choice to think in this way. Thus, in Surfacing, male characters cannot be held responsible for the emotional stress of females.

The definition of feminism is thus vague. How can the words "acceptable" and "bodily autonomy" exist together? Both are contradictory to each other. It is not possible to prescribe a limit to which the "physical activity" would be accepted. It, in fact varies from culture to culture and person to person. The feminist demand of granting "bodily autonomy" to females does not warrant the inclusion of "acceptable physical activity" into the definition. To what extent a woman would like to have bodily autonomy is her freedom of choice and is not subject to the condition of acceptable physical activity, otherwise, it would become meaningless. Such contradictions have made feminism a debatable issue. The application of Sartrean theory has made the concept of feminism well defined. In fact, the issue of feminism should be brought in, where women are threatened to act against their will, or when they are physically overpowered which force them to plunge themselves into an action not desired by them, for example, rape.

\section{Application of Sartrean philosophy to Nectar in a Sieve}

As in Surfacing, Nectar in a Sieve also depicts two types of women- one who adopts prostitution as an easy way to earn money, and the other who in spite of adverse circumstances does not give up her sanctity.

Rukmani belonged to a well-off family, but she was married to a poor village farmer, Nathan. In the beginning, she felt quite uncomfortable at her new home which was a two-room mud hut with thatched roof beside a rice paddy field, but she never complained her husband. She tried to adjust herself with the lifestyle. She learnt from the neighborhood women- how to milk the goat, plant seeds, churn butter and mull rice. She was happy that she was married to a man who is a man of character. When she was comparing herself with Kunti, she says- "For myself, I am glad I married 'beneath me', for a finer man no one could have had; but possible she was not lucky"(Markandaya, 2009 , p.10). She sees the goodness of her husband. She herself said that it is not easy for him to see his wife more learned but not once he tried to assert his rights and forbid her of her pleasures, as lesser men might have done (Markandaya, 2009, p.14).Rukmani did not compromise with her character even during hard times, when the long incessant rain had deprived them of everything- food, shelter and clothes. Her youngest son Kuti, who was not yet five was on the verge of death because of starvation. Rukmani's heart rendering words - "and I would go to him with beating heart to see if the fight was ended; but again and again he struggled back to consciousness, took up again his tormented living; almost I wished it otherwise" (Markandaya, 2009, p. 97) confirms the graveness of the situation.

Irawaddy, however, could not bear the condition of her brother and took to prostitution. She got buckled down by the vagaries of life. Her parents tried to prevent her from doing so, but she did not budge. While her mother, Rukmani never thought of resorting to prostitution rather she was prepared to lose her son. It is seen that none of the characters in the novel were responsible for Irawaddy's plight. She deliberately chose to become a prostitute by 
operating her "freedom of choice" and hence responsible for its repercussions- possible hatred by the society may be one of them. As far as the estrangement by her husband is concerned, it seems to me that he was least responsible for her sufferings. In the Indian context, it is well established that sons are valued more than daughters. This disparity is more commonly observed in villages. The status of women was a major issue during the time when this novel was written. The novel was published in 1954, when India was confronting with new political concepts and political upheavals. The new laws granting rights to women were not enacted until after Independence. Procreation was considered so important that if a woman failed to conceive, he could take another wife.The birth of a girl child was considered a burden. All these issues are well addressed by Markandaya in her novel. I being a part of an Indian society, very well know that this mentality has been a part of Indian society over ages, and slowly, it has become a custom- a compulsion for the wife to bear a son.Irawaddy's husband also fell prey to this thinking and he abandoned her as he considered her to be a barren woman, incapable of bearing a son for him.Even Irawaddy's parents did not blame him for for this. Nathan says: "I do not blame him". "He is justified, for a man needs children. He has been patient". Irawaddy's mother also accepted the reason as justified though she said that he should have waited for some more time- "Not patient like you, beloved" (Markandaya, 2009, p. 52). When Irawaddy's husband took another woman, then also she did not blame him- "you must not blame him. He has taken another woman."

Kunthi is shown as a woman who is happy making the money by trading her body. She is not forced by anybody to adopt prostitution. Janaki, a village woman says-"She is a trollop, and is anxious only that there should be a supply of men" (Markandaya, 2009, p. 49).

Thus, it is seen that all the three women are exactly opposite to each other. Rukmani is shown as a woman of strong will. She is true to herself and ready to accept the things she cannot change. She says in the novel, "what if we gave into our troubles at every step? We would be pitiable creatures indeed to be so weak, for is not a man's spirit given to him to rise above his misfortunes?" (Markandaya, 2009, p. 115). She has accepted the reality and is true to her being as well as to her husband and the life. The two other women, Kunthi and Irawaddy became prostitutes by their choice.

\section{CONCLUSION}

From the above discussion, it can be concluded that since all women on this earth belong to the same gender, hence it would be inappropriate to formulate culture specific definitions of feminism. If one applies Sartrean theory, then it is found that most of the instances which are believed to fall within the domain of feminism are actually not the situations which have amounted to the oppression of women, but in fact, it was their "freedom of choice" to act in that manner. Sartrean theory, in fact, paved the way for arriving at a single universal definition of feminism.

Thus, feminism can be defined in terms of mental faculty, which, if working in consensus with freedom of choice cannot be considered as leading to the oppression of woman, unless, something is physically and forcibly imposed on her against her will.

This definition and theory can be extended to any situation in the world. Is it justified to say that the film Padmaavat has brought disgrace to women? In an open letter to the director Sanjay Leela Bhansali, actor Swara Bhaskar slams him for glorifying Jauhar and Sati. She has raised the following points:

Women have the right to live, despite being raped, sir. Women have the right to live, despite the death of their husbands, male 'protectors', 'owners', 'controllers of their sexuality'.. whatever you understand the men to be.

Women have the right to live independent of whether men are living or not.

Women have the right to live. Period.

Women are not only walking talking vaginas.

Yes, women have vaginas, but they have more to them as well. So their whole life need not be focused on the vagina, and controlling it, protecting it, maintaining it's purity. (Maybe in the 13th century that was the case, but in the 21 st century we do not need to subscribe to these limiting ideas. We certainly do not need to glorify them. )

It would be nice if the vaginas are respected; but in the unfortunate case that they are not, a woman can continue to live. She need not be punished with death, because another person disrespected her vagina without her consent.

There is life outside the vagina, and so there can be life after rape. (I know I 
repeat, but this point can never be stressed enough.)

In general there is more to life than the vagina. (Hindustan Times, 2018)

The points raised by Swara Bhaskar are no doubt apposite , but does this warrant her to raise finger at Padmaavat for glorifying "jauhar".Does "Jauhar" fall within the realm of feminism? "Jauhar"was a traditional Hindu custom of mass self- immolation by women in order to escape capture, enslavement and rape by any foreign invaders when facing certain defeat during a war. They were brought up in an atmosphere where the honor of the women needs to be protected at any cost. They considered it as a matter of prideif it demands the laying down of their lives. It was not cruelty or exhibition of their egotism but an action which gave them self-satisfaction. Hence, from the above discussion, it can be very well deduced that women of that time were acting by their own choice. They didn't feel it to be imposed on them in any way.

Unless, a woman feels some kind of compulsion against her wish to carry out a particular action, it is not justified to raisehue and cry in the name of feminism.

\section{REFERENCES}

[1] Atwood, Margaret. (2009). Surfacing. London: Virago Press.

[2] Burton, Neel. (2012, March 20). Jean-Paul Sartre on Bad faith. Psychology Today. Retrieved from https://www.psychologytoday.com/us/blog/hide-andseek/.../jean-paul-sartre-bad-faith.

[3] Feminism. Wikipedia. Retrieved from https://en.wikipedia.org/wiki/feminism.

[4] I felt like a vagina: Swara Bhaskar slams Sanjay Leela Bhansali in scathing open letter against Padmaavat. (2018, January 29).The Hindustan Times. Retrieved from https:// www.hindustantimes.com/...swara-bhaskar...letter.../storyIOBBnoBcwHQIwou...

[5] Markandaya, Kamala. (2009). Nectar in a sieve. Gurgaon, Haryana: Penguin Books.

[6] Flynn, T. (2004, April 22). Jean Paul Sartre. In Stanford Encyclopedia of Philosophy. Retrieved from https://plato.stanford.edu/entries/sartre/. 